\title{
Soil formation of mafic rocks of north Galicia, Spain. 3 . Chlorite-smectite transformations in weathered chloritized amphibolite
}

J. Zijlstra, E. L. Meijer and P. Buurman (Department of Soil Science and Geology, Agricultural University, P.O. Box 37,6700 AA Wageningen, Netherlands)

Received 22 January 1985; accepted 14 February 1985

\begin{abstract}
Weathering of chlorite through vermiculite to smectite was studied on pure chlorite samples in various stages of weathering. Transformation in the fine fractions had proceded further than in the coarse fractions of the same sample. Formulae for three chlorites and two smectites were calculated.
\end{abstract}

Key-words: mafic rocks, clay mineralogy, chlorite weathering, vermiculite, smectite.

Introduction. The formation of vermiculite from chlorite in serpentinite soils was reported by Garcia \& Delgado (1978) from soils on serpentinite in southern Spain. Ducloux et al. (1976) suggested a closed system with regard to cations for the transformation of chlorite to chlorite/vermiculite and smectite in serpentinite soils of the Massif Central (France), as follows:

Smectite (1) + chlorite $\rightarrow$ interlayered chlorite/vermiculite + smectite (2).

The present study points to a continuous sequence of transformations from chlorite through vermiculite to smectite in an open system. In the following, the definition of vermiculite is an operational one, based on behaviour upon saturation with various cations, glycerol, and heating. It does not imply that the mineral has the crystallographic structure of vermiculite as described by e.g. Walker (1975).

Materials and methods. The material includes four macroscopic chlorite samples and two clay fractions: UB 1, unweathered macroscopic chlorite, larger than $1 \mathrm{~cm}$; UB 2, strongly weathered macroscopic chlorite; UB 3, slightly weathered macroscopic chlorite; sample 81-150, pure macroscopic chlorite; 81-142 and 81-148, clay fractions of almost pure smectite. Samples UB 2 and UB 3 were separated into fractions smaller and larger than $2 \mu \mathrm{m}$. All samples were studied by X-ray diffraction analysis, after the usual pretreatments. The clay sa nples $81-142$ and 148, and the fractions coarser than $2 \mu \mathrm{m}$ of 81-150, UB 1 and UB 3 were chemically analysed.

Results. The mineralogical composition of the samples is given in Table 1. From the chemical analyses, the following formulae were calculated:

Chlorite UB 1:

$\left(\mathrm{Ca}_{0.01} \mathrm{Na}_{0.02} \mathrm{~K}_{0.01}\right)\left(\mathrm{Mg}_{9.19} \mathrm{Al}_{1.67} \mathrm{Fe}_{0.33}^{\mathrm{III}} \mathrm{Fe}_{0.35}^{\mathrm{II}} \mathrm{Cr}_{0.26} \mathrm{Ni}_{0.18} \mathrm{Mn}_{0.02}\right)\left(\mathrm{Si}_{5.72} \mathrm{Al}_{2.28}\right) \mathrm{O}_{20}(\mathrm{OH})_{16}$ 
Table 1. Mineralogical composition of samples.

\begin{tabular}{llll}
\hline Sample & Clorite & Vermiculite & Smectite \\
UB 1 & & & \\
$81-150$ & +++ & - & - \\
UB 3, $>2 \mu \mathrm{m}$ & +++ & - & - \\
UB $2,>2 \mu \mathrm{m}$ & +++ & $\operatorname{tr}$ & - \\
UB 3, $<2 \mu \mathrm{m}$ & $\operatorname{tr}$ & +++ & - \\
UB 2, $<2 \mu \mathrm{m}$ & - & ++ & ++ \\
$81-142$, clay & - & $\operatorname{tr}$ & +++ \\
$81-148$, clay & - & $\operatorname{tr}$ & +++ \\
\hline
\end{tabular}

$\operatorname{tr}=$ traces.

Chlorite UB 3:

$\left(\mathrm{Ca}_{0.17} \mathrm{Na}_{0.03} \mathrm{~K}_{0.02}\right)\left(\mathrm{Mg}_{6.25} \mathrm{Al}_{1.71} \mathrm{Fe}_{1.17}^{\mathrm{III}} \mathrm{Fe}_{1.14}^{\mathrm{II}} \mathrm{Ni}_{0.43} \mathrm{Cr}_{0.06} \mathrm{Mn}_{0.02}\right)\left(\mathrm{Si}_{7.14} \mathrm{Al}_{0.86}\right) \mathrm{O}_{20}(\mathrm{OH})_{16}$

Chlorite 81-150:

$\left(\mathrm{Ca}_{0.12} \mathrm{Na}_{0.02} \mathrm{~K}_{0.01}\right)\left(\mathrm{Mg}_{6.58} \mathrm{Al}_{1.03} \mathrm{Fe}_{1.94}^{\mathrm{III}} \mathrm{Fe}_{0.28}^{\mathrm{II}} \mathrm{Ni}_{0.42} \mathrm{Cr}_{0.12} \mathrm{Mn}_{0.02}\right)\left(\mathrm{Si}_{7.87} \mathrm{Al}_{0.13}\right) \mathrm{O}_{20}(\mathrm{OH})_{16}$

Main differences between these three chlorites are the substitution in the tetrahedral layer $(0.13$ to $2.28 \mathrm{Al})$, the $\mathrm{Mg}$ in the octahedral layer $(6.25$ to 9.19$)$ and varying $\mathrm{Fe}^{\mathrm{II}}$ in the octahedral layer (0.28 to 1.14$)$.

Smectite 81-142:

$\left(\mathrm{Ca}_{0.03} \mathrm{~K}_{0.02} \mathrm{Ba}_{0.40}\right)\left(\mathrm{Mg}_{1.07} \mathrm{Al}_{0.91} \mathrm{Fe}_{2.04}^{\mathrm{III}} \mathrm{Fe}_{0.08}^{\mathrm{II}} \mathrm{Ni}_{0.02} \mathrm{Cr}_{0.08} \mathrm{Mn}_{0.01}\right)\left(\mathrm{Si}_{7.68} \mathrm{Al}_{0.32}\right) \mathrm{O}_{20}(\mathrm{OH})_{4}$

Smectite 81-148 had a similar composition with slightly lower $\mathrm{Mg}$ and higher $\mathrm{Al}$. Ba in this formula is the saturating cation used in the laboratory. Structural charges calculated from these formulae were $0.24 \mathrm{eq} / \mathrm{kg}$ and $0.33 \mathrm{eq} / \mathrm{kg}$ for $81-150$ and UB 3 , respectively. Charge was lower $(0.03 \mathrm{eq} / \mathrm{kg})$ in chlorite UB-1 and much higher in the smectites: $1.05 \mathrm{eq} / \mathrm{kg}$ in $81-142$ and $1.36 \mathrm{eq} / \mathrm{kg}$ in $81-148$. Compensated charge calculated from adsorbed cations is in the same order of magnitude in all samples.

Vermiculite samples were not chemically analysed. The weathering sequence suggests a continuum from chlorite through vermiculite to smectite.

Chlorite-vermiculite interstratifications are encountered in clay separates of the studied soils, but not in the samples that are discussed here. Upon weathering, trioctahedral $\mathrm{Mg}$-chlorites change into di-tri octahedral $\mathrm{Mg}$-Al chlorites. The smectites are dioctahedral and of nontronite composition. Because of the high iron contents in some nontronite samples, partial neogenesis of this mineral through precipitation cannot be excluded.

\section{References}

Ducloux, J., A. Meunier \& B. Velde, 1976. Smectite, chlorite and regular interlayered chlorite-vermiculite in soils developed on a small serpentinite body, Massif Central, France. Clay Minerals 11: 121135 . 
García, A. \& M. Delgado, 1978. Mineralogía de las fracciones arenosas de suelos derarrollados sobre serpentinas en la Sierra de Carratraca (Malaga). Anales de Edafología y Agrobiología 37: 599-620.

Walker, G. F., 1975. Vermiculites. In: J. E. Gieseking (Ed.), Soil components, Vol. 2. Inorganic Components, pp. 155-190. Springer, Berlin.

This synopsis is based on Chapter 6 of the report 'Weathering and soil formation on mafic and ultramafic rocks in N Galicia, Spain' by G. J. van den Born, A. K. Bregt, H. Kok \& J. Zijlstra (editors: P. Buurman \& E. L. Meijer). Research Project J050816 report 1981, 2nd ed. Dept. of Soil Science and Geology, Agricultural University, Wageningen, 1985.193 pp., 32 figs., 24 tables, refs., 12 appendices.

Available as paper copy (order R030P, $f 30$ including postage) or on microfiche (order R030M, f 17.50 including postage) at: NARD, clo Pudoc, P.O. Box 4, 6700 AA Wageningen, Netherlands (telex 45015 blhwg nl.)

\title{
Soil formation on mafic rocks of north Galicia, Spain. 4. Charge characteristics
}

A. K. Bregt ${ }^{1}$, P. Buurman and E. L. Meijer (Department of Soil Science and Geology, Agricultural University, P.O. Box 37, 6700 AA Wageningen, Netherlands)

Received 22 January 1985, accepted 14 February 1985

\begin{abstract}
Point of net zero charge was lower in a serpentinite soil than in a pyrigarnite soil, resulting in a net negative charge in the former and a net positive charge at soil $\mathrm{pH}$ in the latter. PZNC is strongly raised by high free-iron contents, while $\mathrm{pH}$ dependent (CEC) is more strongly related to organic matter than to sesquioxides. At soil $\mathrm{pH}$, positive charge of sesquioxides and negative charge of organic matter approximately compensated each other, and much of the remaining negative charge was due to contribution of layer lattice clays.
\end{abstract}

Key-words: mafic rocks, charge characteristics, CEC, PZNC

Introduction. Exchange properties of soils on mafic rocks are to a large extent determined by iron compounds and organic matter. In 11 soils described from northwest Spain (Van den Born \& Buurman, 1985), total iron (as \% (w/w) $\mathrm{Fe}_{2} 0_{3}$ ) makes up 12-34 \% of the fine earth fraction in serpentinite soils, $4-52 \%$ in soils on chloritized amphibolite, and $7-11 \%$ in pyrigarnite soils, while dithionite-extractable iron

\footnotetext{
1 Present address: Soil Survey Institute, P.O. Box 98, 6700 AB Wageningen, Netherlands.
} 